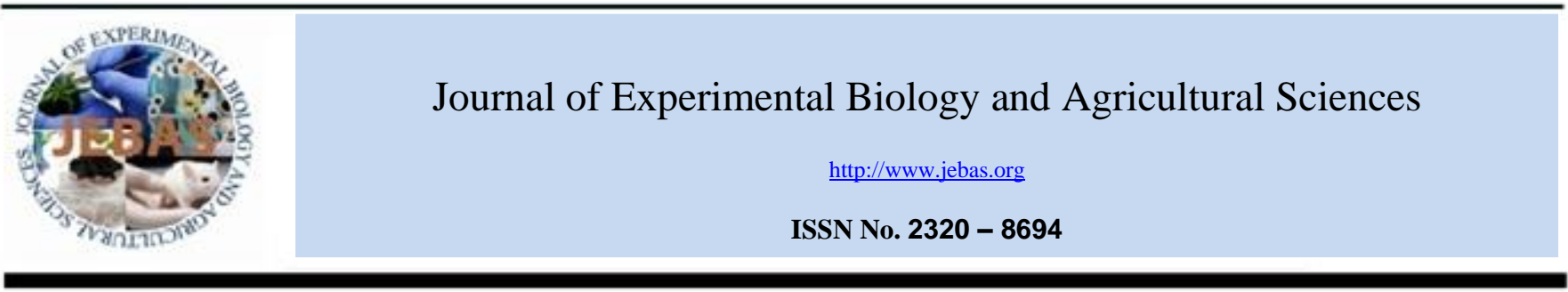

\title{
STUDIES ON ENDOPHYTIC Burkholderia sp. FROM SUGARCANE AND ITS SCREENING FOR PLANT GROWTH PROMOTING POTENTIAL
}

\section{R. Arthee ${ }^{*}$ and P. Marimuthu}

Department of Agricultural Microbiology, Tamil Nadu Agricultural University, Coimbatore-03

Received - March 31, 2017; Revision - April 27, 2017; Accepted - May 01, 2017

Available Online - May 12, 2017

DOI: http://dx.doi.org/10.18006/2017.5(2).242.257

\begin{abstract}
KEYWORDS
Burkholderia

MALDI-TOF MS

Plant growth promotion

Phylogeny

ABSTRACT

The occurrence of Burkholderia genus as plant endophyte indigenous to locally cultivated sugarcane crop was studied. Totally 22 endophytic isolates were obtained from TB-T medium plates of which 10 were found to be putatively endophytic in sugarcane. The morphological, biochemical and MALDI-TOF MS analysis were done and 5 endophytic Burkholderia sp. isolates were identified. Among them, the isolate Burkholderia sp. ES4 shown maximum; diazotrophic activity (total nitrogen: $11.9 \mathrm{mg} \mathrm{g}^{-1}$ of malate; nitrogenase activity: $578.3 \mathrm{n} \mathrm{mol} \mathrm{C}_{2} \mathrm{H}_{4}$ released $\mathrm{h}^{-1} \mathrm{mg}^{-1}$ protein), mineral solubilization activity $\left(10.2 \mathrm{~mm}, 8.2 \mathrm{~mm}\right.$ and $3.2 \mathrm{~mm}$ solublization zone of $\mathrm{P}, \mathrm{ZnO}$ and $\mathrm{CaCO}_{3}$ respectively; available phosphorous: $0.72 \mathrm{mg} \mathrm{ml}^{-1}$ ), antagonistic activity (54.56 percent inhibition of Colletotrichum falcatum mycelium) and phytohormone production (IAA $\left(16.09 \mu \mathrm{g} \mathrm{ml}^{-1}\right)$; GA $\left.\left(10.54 \mu \mathrm{g} \mathrm{ml}^{-1}\right)\right)$, thereby revealing its plant growth promoting potential. The 16S r RNA gene sequence of the isolate Burkholderia sp. ES4 was sequenced and its phylogenetic analysis shown that the isolate forms a monophyletic subclade within the plant-beneficial-environment' (PBE) Burkholderia group. Thus a potent native plant endophytic strain, Burkholderia sp. ES4 that could be developed as biofertilizer inoculum for sugarcane crop, was obtained in this study.
\end{abstract}

* Corresponding author

E-mail: artheerajendran@gmail.com (R. Arthee)

Peer review under responsibility of Journal of Experimental Biology and Agricultural Sciences.

Production and Hosting by Horizon Publisher India [HPI] (http://www.horizonpublisherindia.in/).

All rights reserved.
All the article published by Journal of Experimental Biology and Agricultural Sciences is licensed under a Creative Commons Attribution-NonCommercial 4.0 International License Based on a work at www.jebas.org.

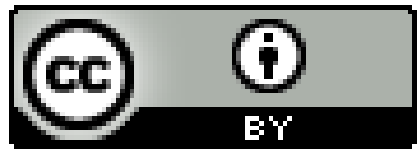




\section{Introduction}

Sugarcane is grown in over 110 tropical and subtropical countries with 50 percent of global production from Brazil and India. The sugarcane rich in sucrose is harvested and to maximize yields high rates of nitrogen $(\mathrm{N})$ fertilizer are often applied. High cost of $\mathrm{N}$ fertilizers and off-site $\mathrm{N}$ losses becomes a problem and inspite of high agronomic input, there is decline in sugarcane yields (Bell et al., 2007). While $\mathrm{N}$ fertilizer used is in the range of $\sim 120$ to $300 \mathrm{~kg} \mathrm{~N} \mathrm{ha}^{-1}$, the global average indicated that only 50 per cent of $\mathrm{N}$ fertilizer applied is used by crops. Reasons of the low fertilizer use efficiency include high soil nitrification rates and weather extremes that promote $\mathrm{N}$ leaching and denitrification (Robinson et al., 2011). In addition, manufacture of synthetic fertilizers uses $\approx 10$ per cent of global energy consumption. One of the methods that can remediate the problems associated with synthetic fertilizers is the use of microrganisms capable of supporting crop growth by their plant growth promoting activities. There are evidences for plant endophytic bacteria enabling to fix nitrogen, promote mineral solubilization, produce plant phytohormones and possess antagonistic property against plant pathogens; without provoking any host plant defence mechanisms by their colonization.

Burkholderia sp. was first described by Walter H. Burkholder in 1950, as Pseudomonas cepacia causing sour skin disease in onions and colonising the rhizosphere of many plant species. The Burkholderia genus comprises human, plant pathogenic and non-pathogenic strains and some species are found to be abundant as endophytes within plants. Initially biological nitrogen fixation (BNF) was reported in B. vietnamiensis (Gillis et al., 1995) of all the species of the genus after this Estrada-de los Santos et al. (2001) reported that Burkholderia could be a genus rich in plant-associated $\mathrm{N}_{2}$ fixers. $B$. kururiensis (Zhang et al., 2000) was identified as a diazotrophic species, and many $\mathrm{N}_{2}$ fixing isolates recovered from different plants (maize, coffee and sorghum) have subsequently been classified within novel Burkholderia sp., including B. unamae (Caballero-Mellado et al., 2004), B. xenovorans (Goris et al., 2004) and B. tropica (Reis et al., 2004). In Tamil Nadu, India improved yield of micropropagated sugarcane by the inoculation of endophytic $B$. vietnamiensis was reported by Govindarajan et al. (2006). Further, many other studies established Burkholderia sp., as an important rhizospheric and endophytic bacterial species (Weilharter et al., 2011; Mitter et al., 2013; Zuniga et al., 2013). Some Burkholderia sp. showed high potential to increase plant nutrient availability by nitrogen fixation and/or phosphate solubilisation, e.g., B. unamae and B. tropica; (Reis et al., 2004), antibiotics or siderophores production (Vial et al., 2011).

Burkholderia sp. has been isolated from intercellular spaces, roots and rhizosphere of sugarcane (James \& Olivares, 1998; Fischer et al., 2012). Paungfoo-Lonhienne et al. (2016) had summarized, that the endophytic association between Burkholderia sp. and sugarcane happens by substantial molecular and morphological adaptations in both the partners, where the first step in the establishment of the association was the formation of a robust bacterial biofilm on roots, by a transition of Burkholderia from a motile state to non-motile multicellular aggregates, typical for bacterial cells within biofilms. The association between Burkholderia Q208 and plants required a significant amount of energy to support bacterial growth and function, including the energy-demanding process of BNF. Burkholderia Q208 activated several pathways by high level of cytochrome bd production leading to glycolysis in both aerobic and anaerobic conditions followed by citric acid cycle in aerobic condition and two pathways viz oxalate catabolism and arsinine deiminase pathway in anaerobic condition thus favouring energy production under both aerobic and microaerobic conditions. The bacteria thus experienced an energy-rich, oxygen-depleted environment, two features required for BNF while being an endophyte. This study was conducted to isolate and identify endophytic Burkholderia sp. from locally cultivated sugarcane plants and screen the isolates for their plant growth promoting activities.

\section{Materials and Methods}

\subsection{Isolation and Enumeration}

All the laboratory experiments were carried out in an aseptic manner in the Department of Agricultural Microbiology, Tamil Nadu Agricultural University (TNAU), Coimbatore and partly in the Department of Soil Science and Agricultural Chemistry, TNAU, Trichy. Triplicate samples of sugarcane root and stem were obtained from fields of different regions of Tamil Nadu, India. The plant samples stored in polyethylene bags were washed thoroughly in tap water to remove the adhering soil particles. Root and stem pieces of $0.5 \mathrm{~cm}$ length were cut, surface sterilized by sequential washing in 70 per cent ethanol for $1 \mathrm{~min}, 2$ per cent $(\mathrm{v} / \mathrm{v})$ sodium hypochlorite for 3 minutes and 70 per cent ethanol for $30 \mathrm{~s}$ and 2 rinses with ample sterilized distilled water. Surface sterilization was verified by plating aliquots $(100 \mu \mathrm{l})$ of the sterile distilled water used in the final rinse onto the plated media. The surface sterilized root and stem segments were separately grounded using a sterile pestle and mortar by using $2 \mathrm{ml}$ of PBS buffer and $1 \mathrm{ml}$ aliquots were plated following dilution plating (Allen, 1953) on the media. Plates were incubated at $28^{\circ} \mathrm{C}$ and the colonies were observed after $48 \mathrm{~h}$. Total gram-negative bacteria was enumerated on a 10\% tryptic soy agar (TSA) medium containing tryptic soy agar $(4 \mathrm{~g} / \mathrm{l})$, agar $(15 \mathrm{~g} / \mathrm{l})$ and crystal violet $(0.005 \mathrm{~g} / \mathrm{l})$ to reduce the growth of gram-positive bacteria (Gould et al., 1985). The Burkholderia sp. isolation medium (TB-T) contained the following components (per liter): $20 \mathrm{~g}$ of agar, $2 \mathrm{~g}$ of glucose, $1 \mathrm{~g}$ of L-asparagine, $1 \mathrm{~g}$ of $\mathrm{NaHCO}_{3}, 500 \mathrm{mg}$ of $\mathrm{KH}_{2} \mathrm{PO}_{4}, 100 \mathrm{mg}$ of $\mathrm{MgSO}_{4}-7 \mathrm{H}_{2} 0,50 \mathrm{mg}$ of trypan blue (TB), and $20 \mathrm{mg}$ of tetracycline (T) (Hagedorn et al.,1987). The $\mathrm{pH}$ of the medium was adjusted to 5.5 with $10 \%$ phosphoric acid $(4 \mathrm{ml} / \mathrm{l})$, and the filter-sterilized tetracycline was added to the autoclaved medium. Total Burkholderia sp. count was enumerated and the bacterial colonies obtained from TB-T medium plates were purified by 
streak plate technique and stored for further studies. They were numerically numbered, with the prefix as ER (Endophytic isolate from Root) and ES (Endophytic isolate from Stem). The isolates were subjected to putative endophtic authentication by inoculating the gnotobiotically (Figure1) grown sugarcane plantlet from apical meristem explant that shown nil contamination when grown in shoot apex medium (White, 1963). The bacteria re-isolated from the inoculated plantlet by plating the macerated tissue were used for further analysis.

\subsection{Characterization of Burkholderia sp.}

Observations of colony morphology (Gerhardt et al., 1981); motility (Skerman, 1967); growth on differential carbon substrate utilization using BMGM medium (Paulina et al., 2001) one lacking azelaic acid but supplemented with a single carbon source $(0.5 \%$ fructose, glucose, sucrose, mannitol, glycerol, malate, succinate); catalase (Smibert \& Krieg, 1981); oxidase (Collins \& Lyne, 1970); citrate utilization (Huhtanen et al., 1972); starch hydrolysis (Seeley \& van Dekark, 1981); cellulase activity (Rautela \& Cowling, 1966) and pectinase activity (Albersheim, 1966) were undertaken to understand the bio-chemical characteristics of the isolates.

\subsection{Identification of the genus Burkholderia sp.}

Isolates that were characterized to be Burkholderia sp., were identified by the method of matrix-assisted laser desorption ionization - time of flight (MALDI-TOF) mass spectrometry and MALDI Biotyper. The Bruker Biflex IV MALDITOF spectrometer (equipped with a UV nitrogen laser [337 nm] and a dual microchannel microplate detector) and MALDI Biotyper 2.0 software (Bruker Daltonics, Bremen, Germany) were used. Samples for the analysis were prepared according to manufacturers' recommendations: after $24-48 \mathrm{~h}$ of cultivation of an isolate on $\mathrm{LB}$ medium at $28^{\circ} \mathrm{C}$, a single colony was transferred with a sterile tip onto the MALDI target in triplicates, drizzled with $1 \mu \mathrm{L}$ of a saturated solution of $\alpha$-cyano-4-hydroxycinnamic acid (Sigma-Aldrich) in organic solution (50\% acetonitrile, $2.5 \%$ trifluoroacetic acid), and directly screened. The measurement of the spectra was performed as described by Uhlik et al. (2011). The matching of unknown spectra to the reference database is based on dedicated score (point) values. This value is used for calculating the final score, according to which the identification results are evaluated as follows: if the logarithmic value of the final score is between 2.3 and 3, the isolate is identified at the level of species; for values between 2 and 2.3, the identification is secure at the level of genus; for values between 1.7 and 2, the identification at the level of genus is probable and for values lower than 1.7, the identification is not successful.

\subsection{Diazotrophic activity of Burkholderia sp.}

The nitrogen fixing ability of the identified Burkholderia isolates was estimated by their growth in $\mathrm{N}$-free medium (Burris \& Wilson, 1946) followed by estimation of total nitrogen (Humphries, 1956) and estimation of ammonia excretion (Cappuccino \& Sherman, 1992). The nitrogenase activity of the isolates was evaluated by conducting Acetylene Reduction Assay (ARA) by Gas Chromotography (GC) (Chemito GC 7610) following the standard procedure given by Burris (1974) using NfB semi solid medium. After completion of the ARA, the cells were pre-digested by adding $10 \%$ SDS and sonicated briefly. Protein concentration in the resulting distributed mixture of suspension was determined (Lowry et al., 1951). The nitrogenase activity of the bacterial isolate was expressed as $\mathrm{n} \mathrm{mol} \mathrm{C}_{2} \mathrm{H}_{4}$ released $\mathrm{h}^{-1} \mathrm{mg}^{-1}$ protein.

\subsection{Mineral solubilisation potential of Burkholderia sp.}

The extent of the solubilisation of insoluble phosphates by the identified Burkholderia isolates was assessed under in vitro condition. The bacterial isolates were screened for phosphate solubilisation as per the methodology followed by Gupta et al. (1994) on modified Pikovskaya medium. Quantitative assay of available phosphorous estimation was carried out using the method described by Olsen et al. (1954) and the phosphatase activity was done by the method described by (Morton, 1952). Solubilisation potential of zinc oxide by the isolates was examined by observing the ability of the cultures to grow on Tris minimal salt medium supplemented with 0.1 per cent zinc oxide for 10 percent glucose (di Simine et al., 1998), following the agar well diffusion assay. Solubilisation potential of calcium carbonate by the isolates was examined by observing the ability of the cultures to grow on modified Aleksandrov medium (Aleksandrov et al., 1967) substituted with soluble form of potassium and 3 per cent calcium carbonate, following the agar well diffusion assay.

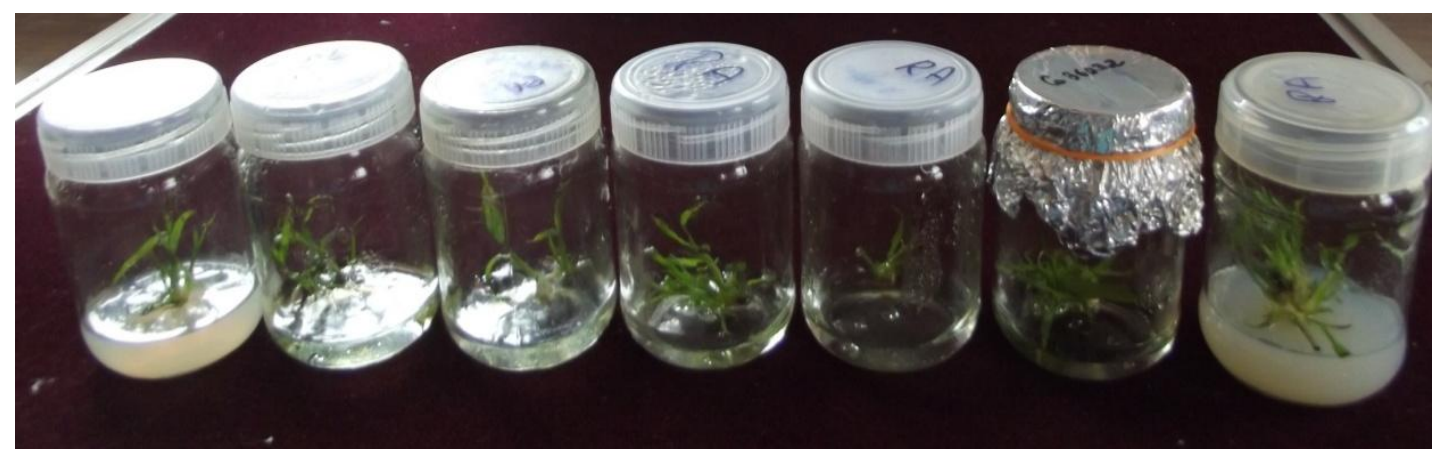

Figure 1 Gnotobiotic studies to identify the putative endophytic bacteria

Journal of Experimental Biology and Agricultural Sciences http://www.jebas.org 
2.6 Antagonistic activity of Burkholderia sp. on sugarcane red rot pathogen Colletotrichum falcatum

Antagonistic activity of all the identified Burkholderia isolates was tested against fungal pathogen, C. falcatum (Cf671), the red rot casual organism in sugarcane obtained from red rot type culture collections in the plant pathology section of the Sugarcane Breeding Institute, Coimbatore, maintained in oat meal agar. The pathogenic fungal disc $(9.0 \mathrm{~mm})$ was placed in the centre of Petri dish containing sterile agar medium. The $48 \mathrm{~h}$ old bacterial isolate to be tested was streak lined at $2 \mathrm{~cm}$ away from the fungal disc on either side (Dennis \& Webster, 1971). The plates were incubated at room temperature $\left(30 \pm 2^{\circ} \mathrm{C}\right)$ for four days and the radial mycelial growth $(\mathrm{mm})$ of the pathogen was recorded and per cent inhibition of the mycelial growth was calculated.

\subsection{Analysis of siderophore production}

Production of siderophores by the identified Burkholderia isolates was performed qualitatively by plate assay (Schwyn \& Neilands, 1987). The Chrome Azurol S (CAS) agar plates were used to check the production of siderophores by bacteria. It is based on the high affinity of siderophores towards ferric iron $\left(\mathrm{Fe}^{3+}\right)$ whereby ferric iron bound to dye, is complexed and released from the dye. The ternary complex chrome azurol S / Fe $e^{3+} /$ hexadecyl trimethyl ammonium bromide served as an indicator. The $48 \mathrm{~h}$ old bacterial isolates were streaked individually on to the agar plates amended with indicator dye prepared. The formation of bright zone with yellowish fluorescence in the dark blue coloured medium indicated positive for siderophore production. The result was scored either positive or negative, based on the colour change of the medium from blue to fluorescent yellow while no colour change marked the absence of siderophore production. Quantification of the siderophore production was done as followed by (Reeves et al., 1983). The culture supernatant was used for the estimation of catecholate type and salicylate type siderophores, by using Hathway reagent. The absorbance was read at $560 \mathrm{~nm}$ (UV-VIS spectrophotometer) and a standard curve was prepared using sodium salicylate for the estimation of salicylate type siderophore and $700 \mathrm{~nm}$ (UV - VIS spectrophotometer) with 2, 3dihydroxybenzoic acid as standard to measure catechol type siderophore. The quantity of siderophore synthesized was expressed as $\mu \mathrm{g} \mathrm{ml}^{-1}$ of culture filtrate.

\subsection{IAA and GA production by Burkholderia sp.}

The quantity of IAA produced by each isolate was estimated by the spectrophotometric technique using van Urk Salkowski's reagent ( $1 \mathrm{ml}$ of $0.5 \mathrm{~N} \mathrm{FeCl}_{3}$ mixed in $50 \mathrm{ml}$ of 35 per cent perchloric acid) following the Salkowski's method (Ehmann, 1977; Ahmad et al., 2005). The quantity of IAA was expressed in $\mu \mathrm{g} \mathrm{ml}^{-1}$ by referring to a standard graph of IAA prepared from a series of IAA solutions of known concentrations. HPLC (Spectra System P1000, Thermo Electron Corporation) with UV detector and C18 colummn $(4.6 \times 150 \mathrm{~mm}$, Nacalai Tesque, Inc. Japan) was used to study the IAA fractions of the isolate that shown maximum IAA production
(Sarwar et al., 1992). The quantity of GA produced by each isolate was estimated by the spectrometric method followed by Mahadevan \& Sridhar (1986). The quantity of GA was expressed in $\mu \mathrm{g} \mathrm{ml}^{-1}$ by referring to a standard graph of GA prepared from a series of GA solutions of known concentrations. The isolate that showed maximum GA production was subjected to HPLC. Hundred $\mathrm{ml}$ of culture broth was centrifuged (Remi, India) at 2817 $\mathrm{xg}$ for $15 \mathrm{~min}$, and supernatant was used for extraction of gibberellic acid. The $\mathrm{pH}$ of supernatant was adjusted to 2.8 with 1 $\mathrm{N} \mathrm{HCl}$ and gibberellic acid was extracted with an equal volume of ethyl acetate. This ethyl acetate extract was evaporated to dryness at $35^{\circ} \mathrm{C}$, and the residue was dissolved in $500 \mu$ l of pure methanol. The samples were analyzed on HPLC (Spectra System P1000, Thermo Electron Corporation) with UV detector and C18 colummn (4.6x150mm, Nacalai Tesque, Inc. Japan) by the method followed by Li et al. (1994).

2.9 Phylogenetic analysis of the endophytic isolate Burkholderia sp. ES4

The genomic DNA from the endophytic isolate Burkholderia sp. ES4, which showed maximum plant growth promoting potential, was extracted using the standard protocol of hexadecyl-trimethyl ammonium bromide (CTAB) method as given by Melody (1997) with minor modifications and the isolated genomic DNA was stored at $-20^{\circ} \mathrm{C}$ for further studies. Full length $16 \mathrm{~S}$ rRNA gene (1500bp) was amplified from the stored genomic DNA using the universal eubacterial forward primer FD1(5' AGAGTTTGA TCGTGGCTCAG 3') and the reverse primer RP2 (5' ACGGCTACCTTGTTACCACTT 3') (Weisburg et al., 1991). The PCR amplification was conducted in a PCR thermal cycler (MyCycler, Bio-Rad Laboratories Inc., USA). The amplified products were purified and sequenced by Bioserve Biotechnologies (India) Pvt. Ltd. (Hyderabad, India). The identity of 16S rRNA gene sequence was performed by similarity search using BLAST tool (http://blast.ncbi.nlm.nih.gov/Blast.cgi). To identify the bacterial strain, 16S rRNA gene sequence was compared with published sequence of closely relates species, strain on NCBI GenBank (Altschul et al., 1997). The phylogenetic tree was constructed using existing 16S rRNA gene sequence database of few other Burkholderia sp, strains in Genbank. The 16S rRNA gene sequences were aligned using CLUSTAL W (Thompson et al., 2013). A phylogenetic tree was constructed by using MEGA 6.0 (Tamura et al., 2013), in which an evolutionary distance matrix was generated as described by Jukes \& Cantor (1969). The evolutionary tree for the dataset was inferred from the neighborjoining method of Saitou \& Nei (1987). The stability of relationships was assessed using bootstrap analysis of the neighbor-joining data based on 1000 resamplings.

\subsection{Statistical analysis}

All the data given in the tables were the mean of triplicate values obtained. Basic statistical parameters were calculated using AGRESS in Microsoft Excel of Windows 2010. 
Table 1 Enumeration of endophvtic gram negative bacterial colonies from sugarcane

\begin{tabular}{|c|c|c|c|c|}
\hline \multirow{2}{*}{$\begin{array}{l}\text { Sample } \\
\text { No. (S) }\end{array}$} & \multirow[t]{2}{*}{ Plant part $(\mathrm{P})$} & \multicolumn{2}{|c|}{ Count of bacteria recovered from } & \multirow{2}{*}{$\begin{array}{c}\% \text { of } \\
\text { Burkholderia } \text { sp. isolates recovered }\end{array}$} \\
\hline & & $10 \%$ TSA $X 10^{6}(\mathrm{C} 1)$ & TB-T $X 10^{5}(\mathrm{C} 2)$ & \\
\hline \multirow[t]{2}{*}{1} & $\operatorname{Root}(\mathrm{P} 1)$ & 13.3 & 2.7 & 20.3 \\
\hline & Stem $(\mathrm{P} 2)$ & 9.7 & 4.3 & 44.3 \\
\hline \multirow[t]{2}{*}{2} & Root & 10.7 & 2.0 & 18.7 \\
\hline & Stem & 6.7 & 1.3 & 19.4 \\
\hline \multirow[t]{2}{*}{3} & Root & 8.0 & 3.0 & 37.5 \\
\hline & Stem & 6.7 & 0.7 & 10.4 \\
\hline \multirow[t]{2}{*}{4} & Root & 12.3 & 1.7 & 13.8 \\
\hline & Stem & 5.0 & 0.3 & 6.0 \\
\hline \multirow[t]{2}{*}{5} & Root & 12.3 & 3.0 & 24.4 \\
\hline & Stem & 7.0 & 1.7 & 24.3 \\
\hline \multirow[t]{2}{*}{6} & Root & 9.3 & 3.0 & 32.3 \\
\hline & Stem & 4.0 & 2.0 & 50.0 \\
\hline \multirow[t]{2}{*}{7} & Root & 11.0 & 1.0 & 9.1 \\
\hline & Stem & 6.0 & 1.0 & 16.7 \\
\hline \multirow[t]{2}{*}{8} & Root & 12.0 & 1.0 & 8.3 \\
\hline & Stem & 8.7 & 1.0 & 11.5 \\
\hline \multirow[t]{2}{*}{9} & Root & 12.0 & 2.0 & 16.7 \\
\hline & Stem & 8.7 & 1.7 & 19.5 \\
\hline \multirow[t]{2}{*}{10} & Root & 11.3 & 1.7 & 15.0 \\
\hline & Stem & 8.0 & 2.0 & 25.0 \\
\hline SEd & 0.86 & 0.38 & 0.86 & 1.22 \\
\hline $\mathrm{CD}(0.05)$ & 1.71 & 0.77 & 1.71 & 2.42 \\
\hline
\end{tabular}

Statistical significant differences among the treatments were analysed using ANOVA (Analysis of Variance) and multiple comparison test was done using LSD (Least Significance Difference) where the significance was evaluated at $\mathrm{p}<0.05$ for all tests.

\section{Results and Discussion}

In the present study, sugarcane root and stem samples were collected in triplicates from 10 different regions of sugarcane fields in Tamil Nadu, India. Gram negative bacterial colonies and Burkholderia sp. were enumerated using 10\%TSA medium and TB-T medium respectively (Table 1 ). Among the 10 sample sets collected, sample 1 root showed maximum $\left(13.3 \times 10^{6} \mathrm{ml}^{-1}\right)$ gram negative bacterial count and it was followed by samples 4 and 5 roots $\left(12.33 \times 10^{6} \mathrm{ml}^{-1}\right)$ and minimum count was observed in sample 6 stem $\left(4.0 \times 10^{6} \mathrm{ml}^{-1}\right)$. On statistical analysis sample 1 root emerged to be the single sample with maximum gram negative bacterial population while all the other sample sets remained on par. Among the 10 sample sets collected, sample 1 stem showed maximum $\left(4.3 \times 10^{5} \mathrm{ml}^{-1}\right)$ Burkholderia sp count followed by samples 3,5 and 6 roots $\left(3.0 \times 10^{5} \mathrm{ml}^{-1}\right)$ and minimum count was observed in sample 4 stem $\left(0.3 \times 10^{5} \mathrm{ml}^{-1}\right)$. On statistical analysis it was found that mostly root samples harboured more Burkholderia sp. population than stem except the sample 1 stem population. Also the percentage of Burkholderia sp. isolates recovered was found to be highest $(50 \%)$ from sample 6 stem followed by sample1, stem $(44.3 \%)$, least $(6 \%)$ in sample 4 stem. Also for each sample set, bacterial counts with the selective medium (TB-T) were much lower than the count of total gram negative colonies. On TB-T medium the Burkholderia sp. colonies appeared to be white or yellow and the proportion of pigmented colonies differed among samples. Hagedorn et al. (1987) have shown that the TB-T medium provided high degree of selectivity for and detection of Burkholderia sp. upon initial plating from soil samples.

The other most commonly used PCAT medium was not completely specific for Burkholderia $s p$. since some gamma-proteobacteria episodically grew in this medium (Pallud et al., 2001). Species abundance and diversity of $B$. cepacia complex in the environment was studied by Ramette et al. (2005) in which TB-T was chosen over other $B$. sp. semi-selective media, because all known Burkholderia species can grow on it and it yields more Burkholderia isolates than other media. Isolation and identification of Burkholderia sp. from onion rhizosphere by Jacobs et al. (2008) shown that B. cepacia and B. ambifaria were preferentially recovered on TB-T medium, with $79 \%$ and $80 \%$ of the total isolates, respectively. 
Table 2 Cultural morphology of bacterial endophytes isolated from sugarcane

\begin{tabular}{|c|c|c|c|c|c|}
\hline \multirow[t]{2}{*}{ Isolate } & \multicolumn{4}{|c|}{ Colony morphology } & \multirow[t]{2}{*}{ Motility } \\
\hline & Colour & Elevation & Margin & Texture & \\
\hline ER2 & Creamy white & Raised & Smooth & Dry & + \\
\hline ER5 & Dull white & Flat & Smooth & Dry & + \\
\hline ER8 & Creamy white & Raised & Smooth & Mucous & + \\
\hline ER9 & Creamy white & Raised & Wavy & Dry & + \\
\hline ER11 & Pale yellow & Flat & Smooth & Dry & + \\
\hline ES2 & Dull yellow & Flat & Smooth & Dry & + \\
\hline ES3 & Dull yellow & Flat & Smooth & Dry & + \\
\hline ES4 & Dull yellow & Flat & Smooth & Dry & + \\
\hline ES8 & Dull yellow & Flat & Smooth & Dry & + \\
\hline ES9 & Creamy white & Raised & Smooth & Dry & + \\
\hline
\end{tabular}

Table 3 Differential biochemical characteristics of bacterial endophytes isolated from sugarcane

\begin{tabular}{|c|c|c|c|c|c|c|}
\hline Isolate & Catalase & Oxidase & Cellulase & $\begin{array}{c}\text { Starch } \\
\text { hydrolysis }\end{array}$ & $\begin{array}{c}\text { Citrate } \\
\text { utilization }\end{array}$ & Pectinase \\
\hline ER2 & + & + & + & - & + & - \\
\hline ER5 & + & + & + & + & + & + \\
\hline ER8 & + & + & + & + & + & - \\
\hline ER9 & + & + & + & + & + & + \\
\hline ER11 & + & + & + & + & + & + \\
\hline ES2 & + & + & + & - & + & - \\
\hline ES3 & + & + & + & + & + & - \\
\hline ES4 & + & + & + & + & + & + \\
\hline ES8 & + & + & + & - & + & - \\
\hline ES9 & + & + & + & + & + & - \\
\hline
\end{tabular}

Table 4 Differential carbon substrate utilization of the isolated bacterial endophytes from sugarcane

\begin{tabular}{|c|c|c|c|c|c|c|c|}
\hline Isolate & Glucose & Fructose & Sucrose & Mannitol & Glycerol & Malate & Succinate \\
\hline ER2 & + & + & + & + & + & + & + \\
\hline ER5 & + & + & + & - & - & + & + \\
\hline ER8 & + & + & + & - & + & - & + \\
\hline ER9 & + & + & + & + & - & + & + \\
\hline ER11 & + & + & + & + & + & + & + \\
\hline ES2 & + & + & + & + & - & + & + \\
\hline ES3 & + & + & + & + & + & - & + \\
\hline ES4 & + & + & + & + & + & + & + \\
\hline ES8 & + & + & + & + & + & + & + \\
\hline ES9 & + & + & + & + & + & + & + \\
\hline
\end{tabular}

Totally 22 endophytic bacterial isolates were obtained from TB-T medium plates, 12 from root samples and 10 from stem samples. The isolates re-isolated from, the macerated tissue culture plant samples raised gnotobiotically and inoculated with the corresponding isolate, were confirmed to be putative endophytic bacterial isolates, which reduced the isolate collection to 10 in number, viz ER2, ER5, ER8, ER9, ER11, ES2, ES3, ES4, ES8 and ES9. There are only a handful number of gnotobiotic studies on plant endophytic Burkholderia sp. interactions with sugarcane (Compant et al., 2005; Paungfoo-Lonhienne et al., 2014; PaungfooLonhienne et al., 2016). These studies indicated that large numbers of bacteria dwell at the surface of roots, and some occur inside root cortex cells. Movement of bacterial cells with cytoplasmic streaming had confirmed their localization inside living root cells. These results indicated that Burkholderia sp. had endophytic associations with sugarcane. 


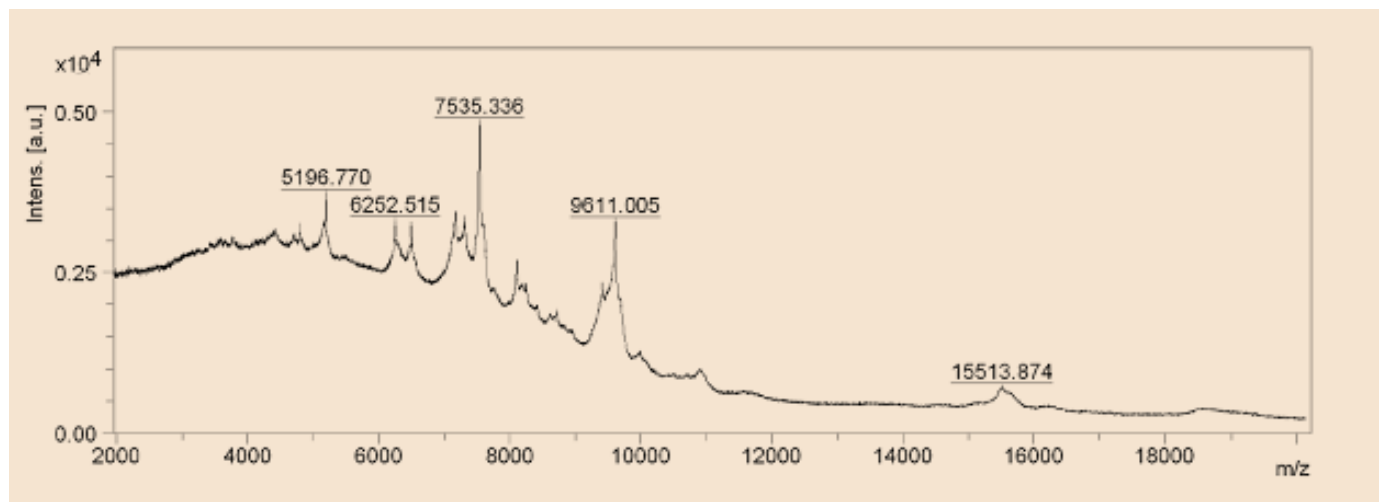

Figure 2 Representative spectra profile (with score values > 2.0) of the endophytic isolate Burkholderia sp. ES4 associated with sugarcane

The 10 putative endophytic Burkholderia sp. isolates were mostly white or yellow in color with mostly flat, smooth and dry colony characteristics as described by Hagedorn et al. (1987) (Table 2). All the 10 shown motility, catalase and oxidase positive. Cellulose and citrate utilization was found in all the 10 isolates. Only few isolates (ER5, ER9. ER11 and ES4) were found to be pectinase positive and few more isolates shown starch hydrolysis (Table 3 ).

Table 5 Identification of the genus Burkholderia sp. using MatrixAssisted Laser Desorption/Ionization - Time of Flight Mass Spectrometer (MALDI-TOF MS)

\begin{tabular}{|lllll|}
$\begin{array}{l}\text { S. } \\
\text { No. }\end{array}$ & $\begin{array}{l}\text { Isolate } \\
\text { Code }\end{array}$ & $\begin{array}{l}\text { Identification using } \\
\text { MALDI-TOF MS }\end{array}$ & $\begin{array}{l}\text { Score } \\
\text { value }\end{array}$ & $\begin{array}{l}\text { Plant } \\
\text { sample }\end{array}$ \\
\hline $\mathbf{1}$ & ER2 & Bacillus sp. & 2.081 & Root \\
\hline $\mathbf{2}$ & ER5 & Burkholderia sp. & 2.064 & Root \\
\hline $\mathbf{3}$ & ER8 & Not identified & - & Root \\
\hline $\mathbf{4}$ & ER9 & Not identified & - & Root \\
\hline $\mathbf{5}$ & ER11 & Not identified & - & Root \\
\hline $\mathbf{6}$ & ES2 & Burkholderia sp. & 2.073 & Stem \\
\hline $\mathbf{7}$ & ES3 & Burkholderia sp. & 2.011 & Stem \\
\hline $\mathbf{8}$ & ES4 & Burkholderia $\mathrm{sp}$. & 2.176 & Stem \\
\hline $\mathbf{9}$ & ES8 & Burkholderia $\mathrm{sp}$. & 2.059 & Stem \\
\hline $\mathbf{1 0}$ & ES9 & Not identified & - & Stem \\
\hline
\end{tabular}

Reis et al. (2004) had observed that B. tropica sp. nov. showed catalase, oxidase positive and no starch hydrolysis. The differential carbon substrate utilization pattern was studied and almost all the isolates grew in most of the C source tested (Table 4). Only few isolates shown nil growth in mannitol (ER5 and ER8), glycerol (ER5, ER9 and ES2) and malate (ER8 and ES3). Bio-chemical characterization of endophytic plant growth promoting Burkholderia sp. MSSP from root nodules of Mimosa pudica was done by Pandey et al. (2005) and found to have similar results like this study. The phenotypical and biochemical characters of our isolates showed similarity with that of most of plant endophytic Burkholderia sp. The method of Matrix-Assisted Laser Desorption/Ionization - Time Of Flight Mass Spectrometer
(MALDI-TOF MS) was used to identify the Burkholderia sp. by the protein profiling of intact bacterial colonies (Table 5, Figure. 2). Among the 10 endophytic bacterial isolates only 5 isolates (ER5, ES2, ES3, ES4 and ES8) shown the score values >2 corresponding to the genus Burkholderia sp. This technique is based on detection of molecular weight of most abundant cell molecules (presumably proteins and peptides) and using the mass spectra information as a fingerprint for a particular organism (Sauer \& Kliem, 2010). Minimal sample preparation and the speed of data acquisition combined with the high throughput and sample processing automation, make MALDI-TOF MS a valuable screening and identification method (de Bruyne et al., 2011). Isolate V9, B. ambifaria was identified using MALDI-TOF MS, from a collection of maize rhizospheric soil isolates by Kifle \& Laing (2016) to study its plant growth promoting potential. This study had shown that even though isolated using a selective medium, followed by phenotypic and bio-chemical characterization, not all the 10 isolates had the MALDITOF MS spectra corresponding to the genus Burkholderia sp.

The 5 endophytic Burkholderia sp isolates were tested for their ability to grow in $\mathrm{N}$-free medium as qualitative evidence for their diazotrophic potential. All the 5 isolates showed growth in the Nfree medium with the isolate ES4 showing maximum growth. The isolates were further analysed for total nitrogen and ammonia production, in which isolates ER5 and ES4 (11.9 $\mathrm{mg} \mathrm{g}^{-1}$ of malate) showed maximum total nitrogen production and isolate ES4 (3.1 $\mathrm{mg} \mathrm{ml}^{-1}$ ) showed maximum ammonia production followed by the isolate ER5 $\left(2.5 \mathrm{mg} \mathrm{ml}^{-1}\right)$. The ARA results obtained showed that the nitrogenase enzyme activity of the isolate ES4 $(578.3 \mathrm{n}$ mol $\mathrm{C}_{2} \mathrm{H}_{4}$ released $\mathrm{h}^{-1} \mathrm{mg}^{-1}$ protein) was the highest among the other isolates. The statistical analysis inferred that the isolate ES4 showed results on par with the standard culture Gluconacetobacter diazotrophicus PAL5 (obtained from standard culture collection, Dept. of Agricultural Microbiology, TNAU, Coimbatore) (Table $6)$.

Studies on nitrogen fixing endophytic Burkholderia sp. associated with maize plants cultivated in Mexico by Estrada et al. (2002) showed that all the Burkholderia isolates could reduce acetylene 
and also showed the presence of nif $\mathrm{H}$ gene in two of the isolates. Reis et al. (2004) described a novel nitrogen fixing sugarcane plant associated bacteria, B. tropica sp. nov. that shown positive result in acetylene reduction assay. Govindarajan et al. (2006) had studied the performance of a local isolate, B. vietnamiensis MG43, an endophytic nitrogen fixing bacterium from sugarcane, under field conditions and shown increase in sugarcane root colonization and biomass. They have also discussed that the locally isolated bacterium was capable of by-passing the initial competition phase in the plant colonization when compared to the standard strains used. Paungfoo-Lonhienne et al. (2014) described a new species $B$. australis sp. nov. which shown biological nitrogen fixation in sugarcane plantlets grown in axenic conditions. Increased nitrogen concentration in roots of rice was seen when inoculated with $B$. cepacia CS5 previously isolated as an endophyte from the rice plant (Hongrittipun et al., 2014). Also, De Oliveira Silva et al. (2016) had obtained two endophytic Burkholderia sp. (UAGC76 and UAGC78) from sugarcane roots that shown positive growth in $\mathrm{N}$-free medium. Results if present study also show that the endophytic isolate Burkholderia sp. ES4 have prudent potential of biological nitrogen fixation that could be utilized in combination with lesser quantity of inorganic $\mathrm{N}$ fertilizer application and also it can be noticed that the genus Burkholderia, is one among the predominant endophytic bacteria, found distinctly in sugarcane irrespective of geographical location and crop variety.

The 5 endophytic Burkholderia sp. isolates were tested for their mineral solubilization potential. All the 5 isolates showed phosphate and zinc solubilisation, among them isolate ES4 showed maximum phosphate $(10.2 \mathrm{~mm})$ and zinc $(8.2 \mathrm{~mm})$ solubilisation zone (Figure. 3). The available $\mathrm{P}$ was estimated and found to be produced maximum $\left(0.72 \mathrm{mg} \mathrm{ml}^{-1}\right)$ by the isolate ES4.

The isolates were further analysed for phosphatase activity, in which the isolate ES4 showed maximum (5.5 $\mu \mathrm{g}$ of PNP released $\mathrm{ml}^{-1}$ day ${ }^{-1}$ ) activity. The calcium carbonate solubilisation was showed by only 3 (ER5, ER3 and ER4) of the 5 isolates in which isolate ES4 showed maximum $(3.2 \mathrm{~mm})$ solubilisation zone. The statistical analysis inferred that the isolate ES4 had significantly increased mineral solubilization potential when compared to that of standard culture Gluconacetobacter diazotrophicus PAL5 (Table 7).

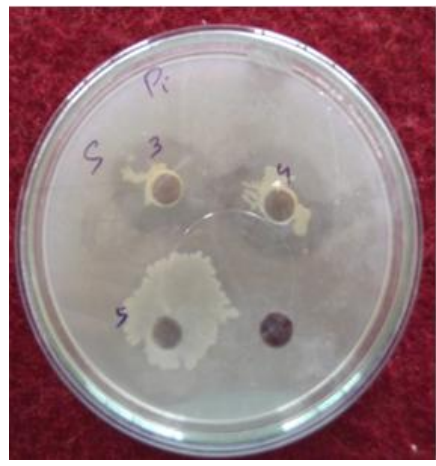

P Solubilisation

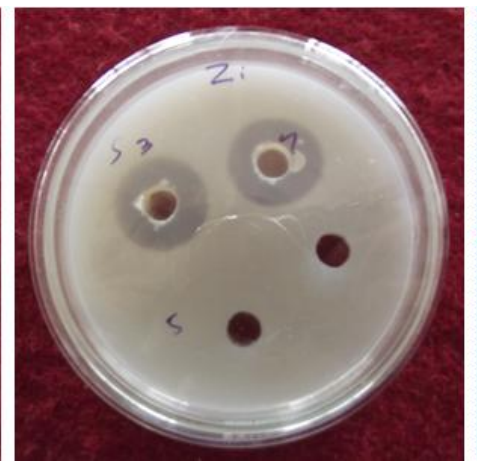

Zn Solubilisation

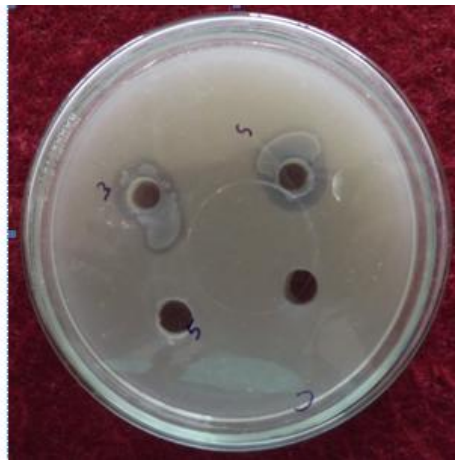

$\mathrm{CO}_{3}$ Solubilisation

Figure 3 Mineral solubilisation potential of the endophytic isolate Burkholderia sp. ES 4

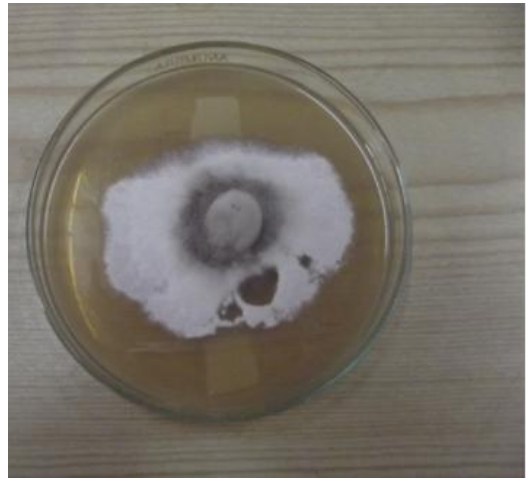

Growth inhibition of Colletotrichum falcatum

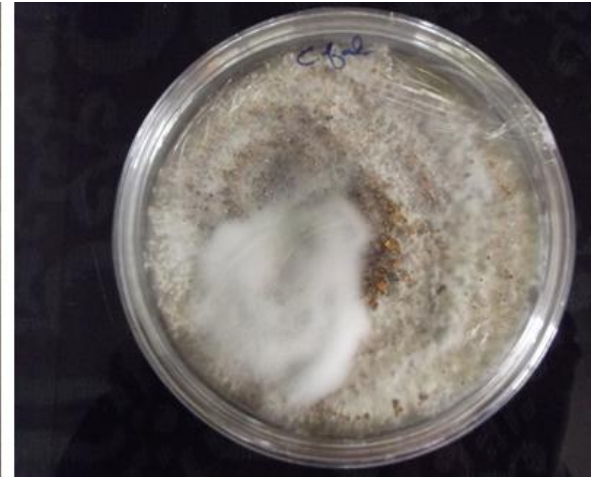

Control plate of Colletotrichum falcatum

Figure 4 Antagonistic activity of the endophytic isolate Burkholderia sp. ES4 on sugarcane red rot pathogen Colletotrichum falcatum 


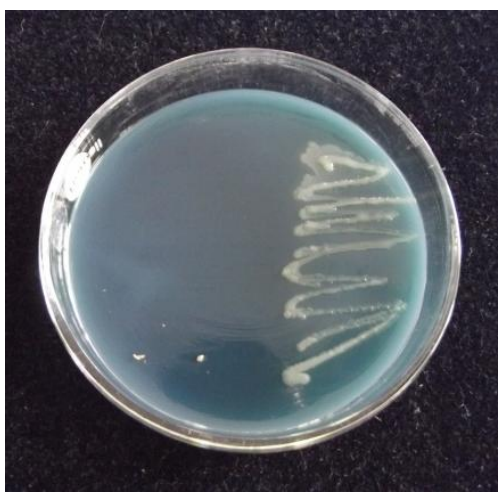

Figure 5 Siderophore production of the endophytic isolate Burkholderia sp. ES 4

Table 6 Assessment of the diazotrophic potential of the endophytic Burkholderia sp.

\begin{tabular}{|c|c|c|c|c|c|c|}
\hline S. No. & $\begin{array}{l}\text { Isolate } \\
\text { Code }\end{array}$ & Isolate & $\begin{array}{l}\text { Growth } \\
\left(A_{660 \mathrm{~mm}}\right)\end{array}$ & $\begin{array}{l}\text { Total nitrogen (mg } \\
\mathrm{g}^{-1} \text { of malate) }\end{array}$ & $\begin{array}{r}\text { Ammonia } \\
\left(\mathrm{mg} \mathrm{ml}^{-1}\right)\end{array}$ & $\begin{array}{l}\text { Nitrogenase activity ( } \mathrm{n} \mathrm{mol} \mathrm{C}_{2} \mathrm{H}_{4} \\
\text { released } \mathrm{h}^{-1} \mathrm{mg}^{-1} \text { protein) }\end{array}$ \\
\hline 1 & ER5 & Burkholderia sp. & +++ & 11.9 & 2.5 & 426.7 \\
\hline 2 & ES2 & Burkholderia sp. & + & 07.2 & 1.8 & 131.3 \\
\hline 3 & ES3 & Burkholderia sp. & ++ & 05.9 & 2.2 & 206.7 \\
\hline 4 & ES4 & Burkholderia sp. & +++ & 11.9 & 3.1 & 578.3 \\
\hline 5 & ES8 & Burkholderia sp. & + & 05.6 & 1.4 & 215.0 \\
\hline Std & PAL5 & $\begin{array}{l}\text { Gluconacetobacter } \\
\text { diazotrophicus }\end{array}$ & +++ & 12.6 & 2.7 & 577.0 \\
\hline \multirow{2}{*}{\multicolumn{3}{|c|}{$\begin{array}{l}\text { SEd } \\
\mathrm{CD}(0.05)\end{array}$}} & & 0.57 & 0.17 & 7.13 \\
\hline & & & & 1.25 & 0.37 & 15.53 \\
\hline
\end{tabular}

No growth $(<0.10 \mathrm{OD}) ;+(0.1-0.3 \mathrm{OD}) ;++(0.3-0.5 \mathrm{OD}),+++(>0.5 \mathrm{OD})$

Table 7 Estimation of solubilization potential of the endophytic Burkholderia sps.

\begin{tabular}{|c|c|c|c|c|c|c|c|}
\hline $\begin{array}{l}\text { S. } \\
\text { No. }\end{array}$ & $\begin{array}{l}\text { Isolate } \\
\text { Code }\end{array}$ & Isolate & $\begin{array}{c}\text { Solublization } \\
\text { zone (mm) }\end{array}$ & 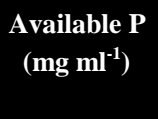 & $\begin{array}{c}\text { Phosphatase activity } \\
\text { ( } \mu \mathrm{g} \text { of PNP released } \\
\text { ml }^{-1} \text { day }^{-1} \text { ) }\end{array}$ & $\begin{array}{c}\mathrm{ZnO} \\
\text { Solublization } \\
\text { zone (mm) }\end{array}$ & $\begin{array}{c}\mathrm{CaCO}_{3} \\
\text { Solublization } \\
\text { zone (mm) }\end{array}$ \\
\hline 1 & ER5 & Burkholderia sp. & 5.1 & 0.35 & 3.3 & 6.3 & 1.8 \\
\hline 2 & ES2 & Burkholderia sp. & 4.3 & 0.13 & 2.1 & 4.2 & - \\
\hline 3 & ES3 & Burkholderia sp. & 4.0 & 0.34 & 2.5 & 3.8 & 2.1 \\
\hline 4 & ES4 & Burkholderia sp. & 10.2 & 0.72 & 5.5 & 8.2 & 3.2 \\
\hline 5 & ES8 & Burkholderia sp. & 7.2 & 0.50 & 2.8 & 2.2 & - \\
\hline Std & PAL5 & $\begin{array}{l}\text { Gluconacetobacter } \\
\text { diazotrophicus }\end{array}$ & 5.1 & 0.42 & 5.1 & 5.2 & - \\
\hline \multicolumn{3}{|c|}{ SEd } & 0.18 & 0.02 & 0.30 & 0.21 & 0.14 \\
\hline \multicolumn{3}{|c|}{$\mathrm{CD}(0.05)$} & 0.40 & 0.05 & 0.63 & 0.50 & 0.35 \\
\hline
\end{tabular}

In calcareous soils, $\mathrm{P}$ is absorbed on the surface of calcium carbonate (Mattingly, 1975), since few of our isolates were obtained from sugarcane plants those cultivated in calcareous soils, we intended to study the calcium carbonate biodissolution potential of the isolates. The endophytic bacteria, during the process of plant colonization, enabling to solubilize the fixed phosphate in the soil and thereby increase its availability to the host plant would be considered as a plant growth promoting potential. In case of sugarcane grown in tropical soils, the inorganic $\mathrm{P}$ fertilizer applied during the time of planting, becomes rapidly fixed.

Journal of Experimental Biology and Agricultural Sciences

http://www.jebas.org 

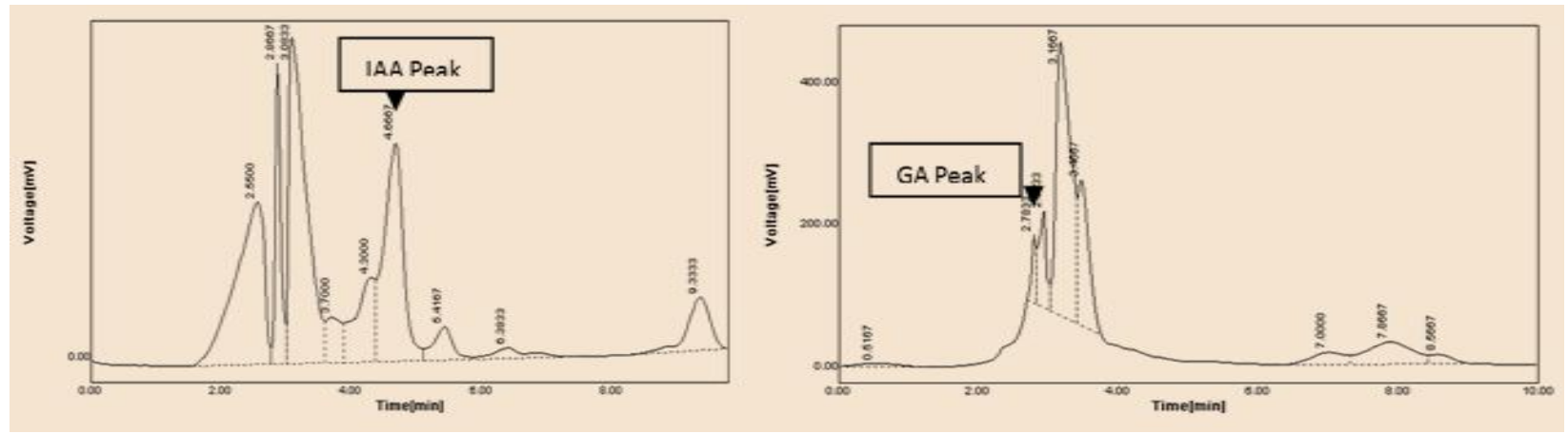

Figure 6 HPLC Chromatograms of IAA and GA production by the endophytic isolate Burkholderia sp. ES 4

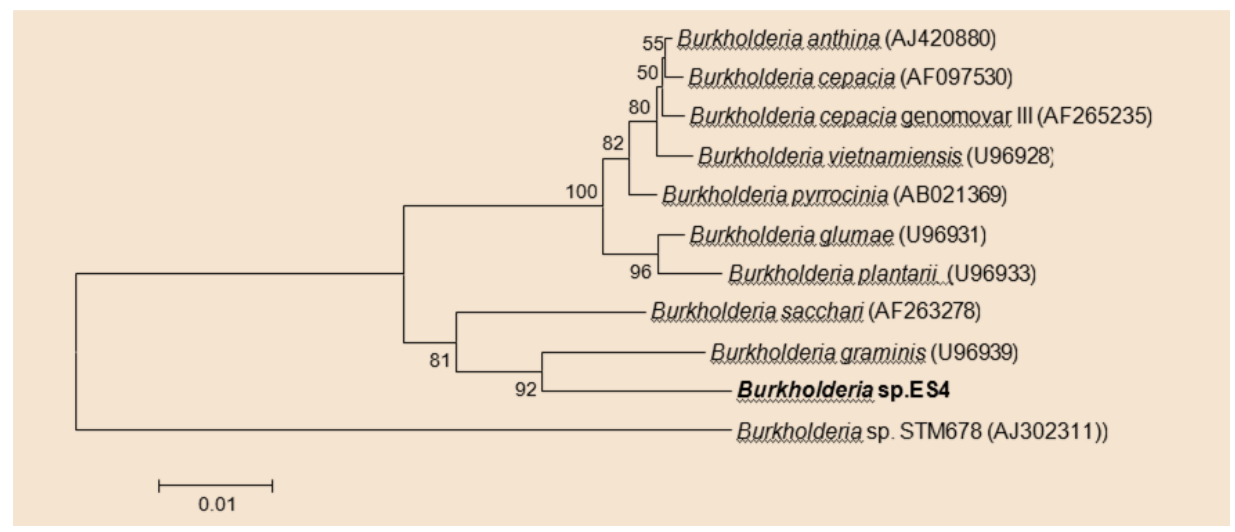

Figure 7 Phylogenetic tree for Burkholderia sp. ES4 based on partial 16S rRNA gene sequences. The tree was generated using the NeighborJoining method (Saitou and Nei, 1987) from Jukes-Cantor calculated distances (Jukes and Cantor, 1969); percentage of 10,000 bootstrap replicates are shown at each node; GenBank sequences of type strains of closely related species are included as references

One way of minimizing this loss is by application of bacterial inoculant or inoculants that can solubilize this $\mathrm{P}$ and transform it as for plant assimilation resulting in better use and crop yield (Wakelin et al., 2004; Canbolat et al., 2006; Dias et al., 2009). Castro-González et al. (2011) have given culturable Burkholderia sp. associated with sugarcane capable of mineral phosphate solubilisation. Studies on Burkholderia sp. showing zinc solublization was conducted by Vaid et al. (2014) and thereafter increase in zinc uptake by the rice plant was also proven.

The antagonistic activity of the 5 endophytic Burkholderia sp. isolates was determined based on the per cent of mycelial growth inhibition of Colletorichum falcatum, the red rot pathogen of sugarcane (Table 8). In this study, isolate ES4 shown maximum inhibition per cent against $C$. falcatum (54.56) (Figure. 4), which was found to be 44.03 per cent more than that of standard culture Gluconacetobacter diazotrophicus PAL5 (10.53) and 4.23 per cent more than that of the standard Bacillus amyloliquefaciens strain (50.33), obtained from the Department of Plant Pathology, TNAU, Coimbatore. One of the means to examine mechanisms by which the bacteria elicit induced systemic resistance of plants is to search for bacterial determinants of elicitation.
In our study the 5 endophytic Burkholderia sp. isolates were tested for siderophore production (Figure. 5) and the estimation of the production was also done. The results in Table 8 indicated that the isolate ES4 produced maximum $\left(14.30 \mu \mathrm{g} \mathrm{mg}^{-1}\right.$ of cells) salicylate type and $\left(12.53 \mu \mathrm{g} \mathrm{mg}^{-1}\right.$ of cells) catechol type siderophores, which were significantly more than that of the standards compared. The secreted siderophores chelate ferric ion $\left(\mathrm{Fe}^{3+}\right)$ with have high affinity, making $\mathrm{Fe}$ available to plant hosts and depriving a pathogen of iron (Schippers et al., 1987).

The roles of siderophores and other antagonistic mechanisms have been poorly described for the genus Burkholderia, except for the isolate B. vietnamensis, for which pyochelin and salicylic acid (catechol type) have been identified by Bevivino et al. (1994). The ability of Burkholderia species to inhibit the growth of multiple soil-borne pathogens on different crops by different antagonistic mechanisms, such as production of antibiotics or siderophores were described by Compant et al. (2008) and Jamalizadeh et al. (2011). 
Table 8 Assessment of antagonistic potential of the endophytic Burkholderia sp.

\begin{tabular}{|c|c|c|c|c|c|}
\hline \multirow{2}{*}{$\begin{array}{l}\text { S. } \\
\text { No. }\end{array}$} & \multirow{2}{*}{$\begin{array}{l}\text { Isolate } \\
\text { Code }\end{array}$} & \multirow[b]{2}{*}{ Isolate } & \multirow{2}{*}{$\begin{array}{l}\text { Antifungal activity } \\
\text { Per cent inhibition }\end{array}$} & \multicolumn{2}{|c|}{ Siderophore type } \\
\hline & & & & $\begin{array}{c}\text { Salicilate } \\
\left(\mu \mathrm{g} \mathrm{mg}^{-1} \text { of cell) }\right.\end{array}$ & $\begin{array}{c}\text { Catechol } \\
\left(\mu \mathrm{g} \mathrm{mg}^{-1} \text { of cell) }\right.\end{array}$ \\
\hline 1 & ER5 & Burkholderia sp. & 50.11 & 10.08 & 6.38 \\
\hline 2 & ES2 & Burkholderia sp. & 49.34 & 5.16 & - \\
\hline 3 & ES3 & Burkholderia sp. & 34.44 & 10.04 & 7.39 \\
\hline 4 & ES4 & Burkholderia sp. & $\mathbf{5 4 . 5 6}$ & 14.30 & 12.53 \\
\hline 5 & ES8 & Burkholderia sp. & 40.12 & 11.60 & 8.20 \\
\hline 6 & PAL5 & $\begin{array}{l}\text { Gluconacetobacter } \\
\text { diazotrophicus }\end{array}$ & 10.53 & 7.53 & 5.32 \\
\hline 7 & Std & Bacillus amyloliquefaciens & 50.33 & 14.07 & 12.14 \\
\hline SEd & & & 0.10 & 0.11 & 0.20 \\
\hline $\mathrm{CD}$ & & & 0.21 & 0.23 & 0.44 \\
\hline
\end{tabular}

Table 9 Quantification of IAA and GA production by the endophytic Burkholderia sps.

\begin{tabular}{|lllll|}
\hline S.No. & Isolate Code & Isolate & IAA $\left(\boldsymbol{\mu g} \mathbf{~ m l}^{\mathbf{- 1}}\right)$ & $\mathbf{G A}\left(\boldsymbol{\mu g} \mathbf{~ m l}^{-\mathbf{1}}\right)$ \\
\hline $\mathbf{1}$ & ER5 & Burkholderia sp. & 11.21 & 6.32 \\
\hline $\mathbf{2}$ & ES2 & Burkholderia sp. & 9.32 & 5.35 \\
\hline $\mathbf{3}$ & ES3 & Burkholderia sp. & 10.50 & 7.08 \\
\hline $\mathbf{4}$ & ES4 & Burkholderia sp. & $\mathbf{1 6 . 0 9}$ & $\mathbf{1 0 . 5 4}$ \\
\hline $\mathbf{5}$ & ES8 & Burkholderia sp. & 12.18 & 9.28 \\
\hline Std & PAL5 & Gluconacetobacter diazotrophicus & 16.12 & 10.11 \\
\hline $\mathbf{S E d}$ & & & 0.17 & 0.17 \\
\hline $\mathbf{C D}(\mathbf{0 . 0 5})$ & & 0.36 & 0.37 \\
\hline
\end{tabular}

Production of plant growth promoting phytohormones (IAA and GA) by the 5 endophytic Burkholderia sp. were estimated spectrophotometrically (Table 9). It was observed that the isolate ES4 shown maximum IAA $\left(16.09 \mu \mathrm{g} \mathrm{ml}^{-1}\right)$ and GA $\left(10.54 \mu \mathrm{g} \mathrm{ml}^{-1}\right)$ production. The IAA production by the isolate ES4 was found to be on par with that of standard culture Gluconacetobacter diazotrophicus PAL5 and GA production was significantly higher than that of standard culture G. diazotrophicus PAL5. Further, qualitative estimation of the IAA and GA produced by the isolate ES4 were observed from the HPLC chromatograms (Figure. 6), in comparison with the standard IAA and GA peaks. The chromatograms shown that the IAA (4.6667 $\mathrm{min})$ and GA (2.9333 min) peaks obtained for the isolate ES4 were found at the same retention times as that of the IAA and GA standards. In our present study the indigenous endophytic Burkholderia sp. were found capable of synthesising IAA and GA. This biosynthesis has been reported to play a major role in the growth and development of the plant including cell division, elongation, differentiation and vascular bundle formation. Higher amount of IAA production increases lateral and adventitious root formation but inhibits the primary root growth (Xie et al., 1996), which is exactly what is needed for root development from sugarcane sett when planted. The production of IAA in B. vietnamiensis has been described by Govindarajan et al. (2008) and in B. kururiensis (rice plant endophyte) by Mattos et al. (2008). Production of GA by Burkholderia sp. has been reported by Joo et al. (2009). Production of GA may modulate the hormonal balance involved in plant defence, including the jasmonate and salicylic acid pathways (Pieterse et al., 2009). The plant hormones IAA and GA, induced by Burkholderia phytofirmans PsJN, had the ability to promote lateral root formation and/or extension in Arabidopsis thaliana (Zhao et al., 2016).

The 16S rRNA gene sequence based phylogenetic tree analysis involving nucleotide sequences of Burkholderia species obtained from NCBI, revealed that the isolate Burkholderia sp. ES4 belonged to the family Burkholderiaceae (Figure. 7). The Burkholderia genus is divided into two main groups (SuárezMoreno et al., 2012). The first group contains Burkholderia species that are pathogens in human, animals and plants. The second group includes non-pathogenic species mostly reported to be associated with and beneficial to plants. The latter group, to which Burkholderia sp. ES4 belongs, is referred to as the 'plantbeneficial-environment' (PBE) Burkholderia group because most have useful properties as antagonists to plant pests, as PGPR, and as organisms that degrade toxic substances (Chiarini et al., 2006). Burkholderia sp. ES4 forms a monophyletic subclade within the PBE group on the tree together with Burkholderia graminis 
(U96939) which is a maize rhizospheric isolate (Veronique et al., 1998). The position of Burkholderia sp. ES4 in the PBE cluster makes it potentially a non-pathogenic bacterium, but this should be evaluated in more detail.

Results of present study showed that sugarcane has been a host plant for endophytic colonization of the genus Burkholderia. Among the 5 endophytic Burkholderia sp., the isolate Burkholderia sp. ES4 has shown maximum plant growth promoting activity like biological nitrogen fixation, mineral solubilisation, antifungal activity against red rot pathogen, siderophore production, IAA and GA production. There are many research papers supporting present work, the main breakthrough of this work was that these isolates were indigenous to the native sugarcane varieties grown in Tamil Nadu, thus could easily colonize the host plant when applied as biofertilizer inoculum.

\section{Acknowledgement}

This research work was supported by Sugar Development Federation, Government of India, with the allotment of funds to the scheme on Formulation of microbial consortium of liquid formulation for sustainable sugarcane production [NRM/CBE/AGM/14/R011].

\section{Conflict of interest}

Authors would hereby like to declare that there is no conflict of interests that could possibly arise.

\section{References}

Ahmad F, Ahmad I, Khan MS (2005) Indole acetic acid production by the indigenous isolates of Azotobacter and Fuorescent pseudomonas in the presence and absence of tryptophan. Turkish Journal of Biology 29:29-34

Albersheim P (1966) Pectin lyase from fungi. Methods in Enzymology 8:628-31. DOI: https://doi.org/10.1016/00766879(66)08113-8.

Aleksandrov VG, Blagodyr RN, Ilev I P (1967) Liberation of phosphoric acid from apatite by silicate bacteria Mikrobiolohichnyĭ zhurnal (Kiev) 29:111-114.

Allen EK (1953) Experiments in Soil Microbiology. Burgess Publication Company, Minnepolis, Minn., p. 107.

Altschul SF, Madden TL, Schäffer AA, Zhang J, Zhang Z, Miller W, Lipman DJ (1997) Gapped BLAST and PSIBLAST: a new generation of protein database search programs. Nucleic Acids Reseache 25: 3389-402. DOI: https://doi.org/10.1093/nar/25.17.3389.
Bell MJ, Stirling GR, Pankhurst CE (2007) Management impacts on health of soils supporting Australian grain and sugarcane industries. Soil and Tillage Research 97:256-271. DOI: http://doi.org/10.1016/j.still.2006.06.013.

Bevivino A, Tabacchioni S, Chiarini L, Carusi MV, Del Gallo M, Visca P (1994) Phenotypic comparison between rhizosphere and clinical isolates of Burkholderia cepacia. Microbiology 140:1069-77. doi: 10.1099/13500872-140-51069.

Burris RH (1974) Biological Nitrogen Fixation. Plant Physiology 54: 443-449

Burris RH, Wilson PW (1946) Ammonia as an Intermediate in Nitrogen Fixation by Azotobacter. Journal of Bacteriolology $52: 505-512$

Caballero-Mellado J, Martı'nez-Aguilar L, Paredes-Valdez G Estrada-de los Santos P (2004) Burkholderia unamae sp nov., an N2-fixing rhizospheric and endophytic species. International Journal of Systematic and Evolutionary Microbiology 54:11651172. DOI 10.1099/ijs.0.02951-0.

Canbolat MY, Bilen S, Cakmakci RS, Ahin F, Aydin A (2006) Effect of plant growth-promoting bacteria and soil compaction on barley seedling growth, nutrient uptake, soil properties and rhizosphere microflora. Biology and Fertility of Soils 42:350357. doi:10.1007/s00374-005-0034-9.

Cappuccino JC, Sherman,N (1992) Microbiology: A Laboratory Manual (third ed), Benjamin/cummings Pub. Co., New York, p.125-179

Castro-González R, Martínez-Aguilar L, Ramírez-Trujillo A, Estrada-de los Santos P, Caballero-Mellado J (2011) High diversity of culturable Burkholderia species associated with sugarcane. Plant and Soil 345:155-169. DOI 10.1007/s11104011-0768-0.

Paungfoo-Lonhienne C, Thierry GA Lonhienne, Yun Kit Yeoh, Bogdan C Donose, Richard I Webb, Jeremy Parsons, Webber Liao, Evgeny Sagulenko, Prakash Lakshmanan, Philip Hugenholtz, Susanne Schmidt, Mark A Ragan (2016) Crosstalk between sugarcane and a plant-growth promoting Burkholderia species. www.nature.com/scientific reports/ 6:37389 | DOI: $10.1038 /$ srep37389

Chiarini L, Bevivino A, Dalmastri C, Tabacchioni S, Visca P (2006) Burkholderia cepacia complex species: health hazards and biotechnological potential. Trends in Microbiology 14:277-286. DOI: http://doi.org/10.1016/j.tim.2006.04.006.

Collins CH, Lyne P M (1970) Microbiological methods, 3rd ed., London, p.126. 
Compant S, Nowak J, Coenye T, Clement C, Ait Barka E (2008) Diversity and occurrence of Burkholderia spp. in the natural environment. FEMS Microbiology 32:607-26. DOI: 10.1111/j.1574-6976.2008.00113.x.

Compant S, Reiter B, Sessitsch A, Nowak J, Clement C, Essaid Ait Barka (2005) Endophytic Colonization of Vitis vinifera $\mathrm{L}$. by Plant Growth-Promoting Bacterium Burkholderia sp. Strain PsJN. Applied Environmental Microbiology 71:1685-1693.

De Bruyne K, Slabbinck B, Waegeman W, Vauterin P, de Baets B, Vandamme P (2011) Bacterial species identification from MALDI-TOF mass spectra through data analysis and machine learning. Systematic and Applied Microbiology 34:20-29. DOI: 10.1016/j.syapm.2010.11.003.

De Oliveira Silva M, Freire FJ, Kuklinsky-Sobral J, de Oliveira ECA, dos Santos Freire MBG, de Oliveira Apolinário VX (2016) Bacteria associated with sugarcane in Northeastern Brazil. African Journal of Microbiology Research 10:15861594. DOI: 10.5897/AJMR2016.8241.

Dennis C, Webster J (1971) Antagonistic properties of species groups of Trichoderma production of non- volatile antibiotics. Transactions of the British Mycological Society 57:25-39. DOI: https://doi.org/10.1016/S0007-1536(71)80077-3.

Di Simine CD, Sayer JA, Gadd GM (1998) Solubilization of zinc phosphate by a strain of Pseudomonas fluorescens isolated from a forest soil. Biology and Fertility of Soils 28:87-94. doi:10.1007/s003740050467.

Dias ACF, Costa FEC, Andreote FD, Lacava PT, Teixeira MA, Assunção LC, Araújo WL, Azevedo JL, Melo IS (2009) Isolation of micropropagated strawberry endophytic bacteria and assessment of their potential for plant growth promotion. World Journal of Microbiology and Biotechnology 25:189195. doi:10.1007/s11274-008-9878-0.

Ehmann A (1977) The Van Urk-Salkowski reagent-a sensitive and specific chromogenic reagent for silica gel thin-layer chromatographic detection and identification of indole derivatives. Journal of Chromatography 132:267-276

Estrada P, Mavingui P, Cournoyer B, Fontaine F, Balandreau J, Caballero-Mellado J (2002) A N2-fixing endophytic Burkholderia sp. associated with maize plants cultivated in Mexico. Canadian Journal of Microbiology 48:285-294.

Estrada-de los Santos P, Bustillos-Cristales R CaballeroMellado J (2001) Burkholderia, a genus rich in plantassociated nitrogen fixers with wide environmental and geographic distribution. Applied and Environmental Microbiology 67:2790-2798. doi: 10.1128/AEM.67.6.27902798.2001.
Fischer D, Pfitzner B, Schmid M, Simoes Araujo JL, Reis VM, Pereira W (2012) Molecular characterisation of the diazotrophic bacterial community in uninoculated and inoculated field-grown sugarcane (Saccharum sp.). Plant and Soil 356:83-99. doi:10.1007/s11104-011-0812-0.

Gerhardt P, Murray RGE, Costilow RN, Nester EW, Wood W A, Krieg NR, Phillips GB (1981) Manual of methods for general bacteriology. Journal of Clinical Pathology 34: 1069.

Gillis M, Van TV, Bardin R, Goor M, Hebbar P, Willems A, Segers P, Kersters, K, Heulin T, Fernandez MP (1995) Polyphasic taxonomy in the genus Burkholderia leading to an emended description of the genus and proposition of Burkholderia vietnamiensis sp. nov. for N2-fixing isolates from rice in Vietnam. International Journal of Systematic Bacteriology 45:274-289

Goris J, De Vos P, Caballero-Mellado J, Park JH, Falsen E, Quensen JF, Tiedje JM, Vandamme P (2004) Classification of the PCB- and biphenyl-degrading strain LB400 and relatives as Burkholderia xenovorans sp. nov. International Journal of Systematic and Evolutionary Microbiology 54 : 1677-1681. DOI 10.1099/ijs.0.63101-0.

Gould WD, Hagedorn C, Bardinelli TR, Zablotowicz RM (1985) New selective media for enumeration and recovery of fluorescent pseudomonads from various habitats. Applied and Environmental Microbiology 49:28-32.

Govindarajan M, Balandreau J, Kwon SW, Weon HY, Lakshminarasimhan C (2008) Effects of the inoculation of Burkholderia vietnamensis and related endophytic diazotrophic bacteria on grain yield of rice. Microbial Ecology 55: 21-37. DOI: doi:10.1007/s00248-007-9247-9.

Govindarajan M, Balandreau J, Muthukumarasamy R, Revathi G, Lakshminarasimhan C (2006) Improved yield of micropropagated sugarcane following inoculation by endophytic Burkholderia vietnamiensis. Plant and Soil 280:239-252. doi:10.1007/s11104-005-3223-2.

Gupta RR, Singal R, Shanker A, Kuhad RC, Saxena RK (1994) A modified plate assay for screening phosphate solubilizing microorganisms. The Journal of General and Applied Microbiology 40:255-260. DOI: http://doi.org/10.2323/jgam.40.255.

Hagedorn C, Gould WD, Bardinelli TR, Gustavson DR (1987) A Selective Medium for Enumeration and Recovery of Pseudomonas cepacia Biotypes from Soil. Applied and Environmental Microbiology 53: 2265-2268

Hongrittipun PL, Youpensuk S, Rerkasem B (2014) Screening of Nitrogen Fixing Endophytic Bacteria in Oryza sativa. 
Journal of Agricultural Science 6:4-10. DOI: http://dx.doi.org/10.5539/jas.v6n6p66.

Huhtanen CN, Naghski J, Dellamonica ES (1972) Microfermentation Series for Identification of Single Colonies of Enterobacteriaceae. Applied Microbiology 24:618-627

Humphries EC (1956) Mineral components and ash analysis. In: Peach K and Tracey MV (Eds.), Modern Methods of Plant Analysis I p. 468-502

Jacobs JL, Fasi AC, Ramette A, Smith JJ, Hammerschmidt R, Sundin GW (2008) Identification and Onion Pathogenicity of Burkholderia cepacia Complex Isolates from the Onion Rhizosphere and Onion Field Soil. Applied and Environmental Microbiology 74: 3121-3129. doi: 10.1128/AEM.01941-07.

Jamalizadeh M, Etebarian HR, Aminian H, Alizadeh A (2011) A review of mechanisms of action of biological control organisms against post-harvest fruit spoilage. EPPO Bulletin 41:7

James EK, Olivares FL (1998) Infection and colonization of sugar cane and other graminaceous plants by endophytic diazotrophs. Critical Reviews in Plant Sciences 17:77-119

Joo GJ, Kang SM, Humayun M, Kim SK, Na CI, Shin DH, Lee IJ (2009) Burkholderia sp. KCTC 11096BP as newly isolated gibberellin producing bacterium. The Journal of Microbiology 47:167-171. doi: 10.1007/s12275-008-0273-1.

Jukes TH, Cantor CR (1969) Evolution of protein molecules. In Munro HN, editor, Mammalian Protein Metabolism, p.21132, Academic Press, New York.

Kifle MH, Laing MD (2016) Isolation and Screening of Bacteria for Their Diazotrophic Potential and Their Influence on Growth Promotion of Maize Seedlings in Greenhouses. Frontiers in Plant Science 6:1225. DOI: https://doi.org/10.3389/fpls.2015.01225.

Li J, Shi J, Zhao XL, Wang G, Yu HF, Ren YJ (1994) Separation and determination of three kinds of plant hormone by high performance liquid chromatography. Fenxi-Huaxue, 22:801-804

Lowry OH, Rosebrough NJ, Farr AL, Randall RJ(1951) Protein measurement with the Folin phenol reagent. Journal of Biological Chemistry 193:265-275

Mahadevan A, Shridhar R (1986) Methods in physiological plant pathology. Madras: Sivakami publications Pp. 213

Mattingly GEG (1975) Labile phosphate in soils. Soil Science 119:369-375.
Mattos KA, Pádua VL, Romeiro A, Hallack LF, Neves BC, Ulisses TM, Barros CF, Todeschini AR, Previato JO, Mendonça-Previato L (2008) Endophytic colonization of rice (Oryza sativa L.) by the diazotrophic bacterium Burkholderia kururiensis and its ability to enhance plant growth. Anais da Academia Brasileira de Ciências 80: 477-493. DOI: http://dx.doi.org/10.1590/S0001-37652008000300009.

Melody SC (1997) Plant Molecular Biology - A laboratory manual. Springer-Verlag, New York.

Mitter B, Petric A, Shin MW, Chain PS, Hauberg-Lotte L, Reinhold-Hurek B, Nowak J, Sessitsch A (2013) Comparative genome analysis of Burkholderia phytofirmans PsJN reveal saw spectrum of endophytic lifestyles based on interaction strategies with host plants. Frontiers in Plant Science 4:120. doi: 10.3389/fpls.2013.00120.

Morton RK (1952) Ph.D Thesis submitted to the University of Cambridge.

Olsen S, Cole C, Watanabe F, Dean L (1954) Estimation of available phosphorus in soils by extraction with sodium bicarbonate. USDA Circular Nr 939, US Government Print. Office, Washington, D.C

Pallud C, Viallard V, Balandreau J, Normand P, Grundmann G (2001) Combined use of a specific probe and PCAT medium to study Burkholderia in soil. Journal of Microbiological Methods 47:25-34. DOI: http://doi.org/10.1016/S0167-7012(01)002871.

Pandey P, Kang SC, Maheshwari DK (2005) Isolation of endophytic plant growth promoting Burkholderia sp. MSSP from root nodules of Mimosa pudica. Current Science 89:5-10

Paulina Estrada-de Los Santos, Rocio Bustillos-Cristales, Jesu 's Caballero-Mellado (2001) Burkholderia, a Genus Rich in Plant-Associated Nitrogen Fixers with Wide Environmental and Geographic Distribution. Applied and Environmental Microbiology 2790-2798. doi: 10.1128/AEM.67.6.27902798.2001/.

Paungfoo-Lonhienne C, Lonhienne TGA, Yeoh YK, Webb RI, Lakshmanan P, Chan CX, Lim PE, Ragan MA, Schmidt S, Hugenholtz P (2014) A new species of Burkholderia isolated from sugarcane roots promotes plant growth. Microbial Biotechnology7:142-154. DOI: 10.1111/1751-7915.12105.

Pieterse CMJ, Leon-Reyes A, Van der Ent S, Van Wees SC (2009) Networking by small-molecule hormones in plant immunity. Nature Chemical Biology 5:308-316. doi:10.1038/nchembio.164. 
Ramette A, LiPuma JJ, Tiedje JM (2005) Species Abundance and Diversity of Burkholderia cepacia Complex in the Environment. Applied and Environmental Microbiology 71:1193-1201. doi: 10.1128/AEM.71.3.11931201.2005.

Rautela GS, Cowling EB (1966) Simple cultural test for relative cellulolytic activity of fungi. Applied Microbiology 14:892-898.

Reeves M, Pine L, Neilands JB, Bullows A (1983) Absence of siderophore activity in Legionella sp. grown in iron deficient media. Journal of Bacteriology 154:324-329.

Reis VM, Estrada-de los Santos P, Tenorio-Salgado S, Vogel J, Stoffels M, Guyon S, Mavingui P, Baldani VL, Schmid M, Baldani JI, Balandreau J, Hartmann A, Caballero-Mellado J (2004) Burkholderia tropica sp. nov., a novel nitrogen-fixing, plant-associated bacterium. International Journal of Systematic and Evolutionary Microbiology 54:2155-2162. DOI 10.1099/ijs.0.02879-0.

Robinson N, Brackin R, Vinall K, Soper F, Holst J, Gamage H, Paungfoo-Lonhienne C, Rennenberg H, Lakshmanan P, Schmidt S (2011) Nitrate paradigm does not hold up for sugarcane. $\quad P L O S \quad O N E$ 6:19-45. DOI: https://doi.org/10.1371/journal.pone.0019045.

Saitou N, Nei M (1987) The neighbor-joining method: a new method for reconstructing phylogenetic trees. Molecular Biology and Evolution 4:406-25. DOI: https://doi.org/10.1093/oxfordjournals.molbev.a040454.

Sarwar M, Arshad M, Martens DA Frankenberger WTJr (1992) Trypthtophan-dependent biosynthesis of auxins in soil. Plant and Soil 147:207-215. doi:10.1007/BF00029072.

Sauer S, Kliem M (2010) Mass spectrometry tools for the classification and identification of bacteria. Natures Reviews Microbiology 8:74-82. doi: 10.1038/nrmicro2243.

Schippers B, Bakker A, Bakker P (1987) Interactions of Deleterious and Beneficial Rhizosphere Microorganisms and the Effect of Cropping Practices. Annual Review of Phytopathology 25:339-358. DOI: 10.1146/annurev.py.25.090187.002011.

Schwyn B, Neilands JB (1987) Universal chemical assay for the detection and determination of siderophores. Analytical Biochemistry 160:47-56. DOI: https://doi.org/10.1016/00032697(87)90612-9.

Seeley JH, Van Demark PJ (1981) Selected exercises from: "Microbes in action: A laboratory manual of microbiology", 3 rd Eds. Freeman, WH. and Co., San Francisco, USA, p. 268.
Skerman VBD (1967) A guide to the identification of the genera of bacteria, 2nd edn. Williams and Wilkins, Baltimore

Smibert RM, Krieg NR (1981) General characterization. In: Gerhardt P (Ed) Manual of Methods for General Bacteriology. American Society for Microbiology 409-443

Suárez-Moreno ZR, Caballero-Mellado J, Coutinho BG, Mendonça-Previato L, James EK, Venturi V (2012) Common features of environmental and potentially beneficial plantassociated Burkholderia. Microbial Ecology 63:249-266. doi: 10.1007/s00248-011-9929-1.

Tamura K, Stecher G, Peterson D, Filipski A, Sudhir Kumar (2013) MEGA6: Molecular Evolutionary Genetics Analysis Version 6.0. Molecular Biology and Evolution 30: 2725-2729. doi: 10.1093/molbev/mst197.

Thompson JD, Gibson TJ, Plewniak F, Jeanmougin F, Higgins DG (2013) The CLUSTAL_X windows interface: flexible strategies for multiple sequence alignment aided by quality analysis tools. Nucleic Acids Research 25: 4876-4882.

Uhlik O, Strejcek M, Junkova P, Sanda M, Hroudova M, Vlcek C, Mackova M, Macek T (2011) Matrix-assisted laser desorption ionization (MALDI)-time of flight mass spectrometry- and MALDI biotyper-based identification of cultured biphenyl-metabolizing bacteria from contaminated horseradish rhizosphere soil. Applied and Environmental Microbiology 77:6858-6866. doi: 10.1128/AEM.05465-11.

Vaid SK, Kumar B, Sharma A, Shukla AK, Srivastava PC (2014) Effect of zinc solubilizing bacteria on growth promotion and zinc nutrition of rice. Journal of Soil Science and Plant Nutrition 14: 889-910.

Vial L, Chapalain A, Groleau MC, Deziel E (2011) The various lifestyles of the Burkholderia cepacia complex species: a tribute to adaptation. Environmental Microbiology 13:1-12. doi: 10.1111/j.1462-2920.2010.02343.x.

Veronique V, Poirier I, Cournoyer B, Haurat J, Wiebkin S, Ophel-Keller K, Balandreau J (1998) Burkholderia graminis sp. nov., a rhizospheric Burkholderia species, and reassessment of [Pseudomonas] phenazinium, [Pseudomonas] pyrrocinia and [Pseudomonas] glathei as Burkholderia. International Journal of Systematic Bacteriology 48:549-563. DOI: 10.1099/00207713-48-2-549.

Wakelin S, Warren R, Harvey P, Ryder M (2004) Phosphate solubilization by Penicillium spp. closely associated with wheat roots. Biology and fertility of soils 40:36-43.

Weilharter A, Mitter B, Shin MV, Chain PSG, Nowak J, Sessitsch A (2011) Complete genome sequence of the plant growth promoting endophyte Burkholderia phytofirmans strain 
PsJN. Journal of Bacteriology 193:3383-3384. doi: 10.1128/JB.05055-11.

Weisburg WG, Barns SM, Pelletier DA, Lane DJ (1991)16S ribosomal DNA amplification for phylogenetic study. Journal of Bacteriology 173: 697-703. doi: 10.1128/jb.173.2.697703.1991.

White PR (1963) The cultivation of Animal and Plant Cells 2ndedition (New York: Ronald Press)

Xie H, Pasternak JJ, Glick BR (1996) Isolation and characterization of mutants of the plant growth-promoting rhizobacterium Pseudomonas putida GR- 122 that overproduce indoleacetic acid. Current Microbiology 32:67-71

Zhang H, Hanada S, Shigematsu T, Shibuya K, Kamagata Y, Kanagawa T, Kurane R (2000) Burkholderia kururiensis sp. nov., a trichloroethylene (TCE)-degrading bacterium isolated from an aquifer polluted with TCE. International Journal of Systematic and Evolutionary Microbiology 50:743-749. doi: 10.1099/00207713-50-2-743.

Zhao S, Wei H, Lin CY, Zeng Y, Tucker MP, Himmel ME, Ding SY(2016) Burkholderia phytofirmans InoculationInduced Changes on the Shoot Cell Anatomy and Iron Accumulation Reveal Novel Components of ArabidopsisEndophyte Interaction that Can Benefit Downstream Biomass Deconstruction. Frontiers in Plant Sciences 7: 24. doi: 10.3389/fpls.2016.00024

Zúñiga A, Poupin MJ, Donoso R, Ledger T, Guiliani N, Gutiérrez RA (2013) Quorum Sensing and Indole-3-Acetic Acid Degradation Play a Role in Colonization and Plant Growth Promotion of Arabidopsis thaliana by Burkholderia phytofirmans PsJN. Molecular Plant-Microbe Interaction 26:546-553. DOI: 10.1094/MPMI-10-12-0241-R.

Journal of Experimental Biology and Agricultural Sciences

http://www.jebas.org 